\title{
Ocena nawyków żywieniowych studentów polskich pierwszego roku medycyny
}

\section{Evaluation of the dietary habits of polish medical students in their first year of studies}

\author{
Aleksandra Gawlikowska-Sroka', Edyta Dzięciołowska-Baran', Jacek Szczurowski² \\ 1 Zakład Anatomii Prawidłowej i Klinicznej Pomorskiego Uniwersytetu Medycznego w Szczecinie \\ al. Powstańców Wlkp. 72, 70-111 Szczecin \\ Kierownik: dr hab. n. med. Zbigniew Ziętek
}

2 Zakład Antropologii Uniwersytetu Przyrodniczego we Wrocławiu

ul. Kożuchowska 6, 51-631 Wrocław

Kierownik: prof. dr hab. Krzysztof Borysławski

\begin{abstract}
SUMMARY
Introduction: One of the most important factors involved in normal growth, maturation, physical activity and mental state is nutrition. Correct patterns formed in youth are necessary to maintain a healthy lifestyle.

The aim of the study was the evaluation of the dietary habits of medical students.

Material and methods: The material consisted of data collected from an anonymous survey distributed among first year students of the Faculty of Medicine and Dentistry ( 66 men and 177 women). The study used a questionnaire of our own design, consisting of open and multi-choice questions concerning the anthropometric data of subjects and nutritional habits. The questionnaire was developed based on the HBSC international standard questionnaire survey on health behaviour in adolescents. Data were analyzed statistically.
\end{abstract}

\section{STRESZCZENIE}

Wstęp: Jednym z najważniejszych czynników warunkujących prawidłowy wzrost, dojrzewanie, aktywność fizyczną i stan psychiczny jest odżywianie. Prawidłowe wzorce ukształtowane w młodości są niezbędne do utrzymania zdrowego stylu życia.

Celem pracy była ocena nawyków żywieniowych studentów I roku wydziału lekarskiego i lekarsko-stomatologicznego.

Materiał i metody: Materiał badawczy stanowiły dane anonimowej ankiety zebranej pośród studentów I roku wydziału lekarskiego i lekarsko-stomatologicznego dotyczące 66 mężczyzn oraz 177 kobiet. Do badań wykorzystano kwestionariusz ankiety własnej konstrukcji składający się z pytań otwartych i pytań wyboru dotyczących danych antropometrycznych badanych osób i zasad odżywiania. Kwestionariusz opracowano w oparciu o międzynarodowy standardowy kwestionariusz z badań nad zachowaniami zdrowotnymi młodzieży szkolnej HBSC. Dane opracowano statystycznie.
Results: The prevalence of obesity was generally not observed in the group of examined students. In most cases body mass index was in the range 18.5-24.99\%. Obesity was observed only in men. There were no significant differences between the groups of men and women in terms of the frequency of regular meals during the week. Only about $50 \%$ of the study population declared regular consumption of the three main meals. Significantly more women than men used slimming diets, and significantly more men took action to control weight. Analysis of the results showed abnormal patterns in the structure of meals.

Conclusions: It is extremely important to educate future doctors in healthy lifestyle, including correct nutrition, through educational programmes during studies.

Key words: nutrition, body mass index, lifestyle.
Wyniki: W grupie badanych studentów nie zaobserwowano występowania problemu otyłości. W większości przypadków wskaźnik masy ciała utrzymywał się w granicach 18,5-24,99\%. Przypadki nadwagi zaobserwowano tylko w grupie mężczyzn. Nie stwierdzono istotnych różnic pomiędzy grupami mężczyzn i kobiet w częstości regularnego spożywania posiłków w ciągu tygodnia. Tylko ok. 50\% badanej populacji deklaruje regularne spożywanie 3 podstawowych posiłków. Kobiety znacząco częściej od mężczyzn stosują diety odchudzające, a mężczyźni znacząco częściej podejmują działania mające na celu kontrolę masy. Analiza wyników wykazała nieprawidłowe wzorce w strukturze spożywanych posiłków.

Wnioski: Studenci medycyny nie stosują zasad zdrowego odżywiania w codziennym życiu. Niezwykle ważne jest kształtowanie wśród przyszłych lekarzy prawidłowych wzorców prozdrowotnych, w tym zasad zdrowego odżywiania poprzez programy edukacyjne podczas studiów.

Słowa kluczowe: odżywianie, wskaźnik masy ciała, styl życia.

\section{WSTĘP}

Prawidłowe odżywianie jest jednym z najważniejszych czynników warunkujących prawidłowy wzrost, dojrzewanie, aktywność fizyczną i stan psychiczny. W Polsce oraz w pozostałych krajach europejskich coraz większego znaczenia nabiera problem otyłości, zwłaszcza u dzieci i młodzieży [1, 2, 3]. Błędy żywieniowe pojawiające się w okresie intensywnego wzrostu i dojrzewania prowadzić mogą do licznych zaburzeń metabolicznych. Rozwojowi otyłości towarzyszy wzrost częstości 
występowania zespołu metabolicznego, cukrzycy, choroby niedokrwiennej i miażdżycy. Nawyki żywieniowe ukształtowane w okresie młodości mają zasadniczy wpływ na sposób odżywiania i stan zdrowia populacji ludzi starszych [2,3]. Morinaka i wsp. [4] zauważyli, że popularyzacja zachodniego stylu odżywiania z konsumpcją dużej ilości produktów typu fast food w miejsce tradycyjnej kuchni japońskiej spowodowała wzrost występowania zespołu metabolicznego w populacji. Problem ten dotyczył 30\% mężczyzn i 10\% kobiet w prefekturze Okinawa. Zmiany sposobu odżywiania i wzrost produktów z wysoką zawartością tłuszczu i cukru obserwowane są również w populacji dzieci i młodzieży w Polsce [1, 2, 3, 4]. Jednocześnie notuje się wysoki odsetek umieralności na choroby układu sercowo-naczyniowego. Ta zła sytuacja epidemiologiczna wiązana jest ze stylem życia przeciętnego Polaka, w którym obserwowane jest często występowanie czynników ryzyka i niska kardioprotekcja, w której istotną rolę pełni dieta i wysiłek fizyczny [5]. W populacji młodych ludzi nieprawidłowe wzorce odżywiania pod postacią nadmiernego objadania się wynikają dość często z problemów radzenia sobie ze stresem [3]. Często również jest to wynik powszechnego pośpiechu i brak ukształtowanych prawidłowych wzorców żywienia uwarunkowanych przez czynniki społeczno-psychologiczne (stopień wykształcenia, poziom wiedzy), demograficzne (pochodzenie społeczne, wielkość rodziny, miejsce zamieszkania, czynniki ekonomiczne - dochody w rodzinie), czy tryb życia, warunki kulturowe i indywidualny smak [6]. Okres studiów dla wielu młodych ludzi oznacza zmianę środowiska życia i podjęcie samodzielności. Ważne jest zatem, aby w tym okresie wzmacniać zachowania prozdrowotne.

Celem pracy była ocena nawyków żywieniowych (rodzaj posiłków, ich częstość, regularność, skład) studentów medycyny I roku wydziału lekarskiego i lekarsko-stomatologicznego.

\section{MATERIA $~ I$ METODY}

Materiał badawczy stanowiły dane anonimowej ankiety zebranej pośród studentów I roku wydziału lekarskiego i lekarsko-stomatologicznego. Informacje uzyskano od 66 mężczyzn oraz 177 kobiet. Do badań wykorzystano kwestionariusz ankiety własnej konstrukcji składający się z pytań otwartych i pytań wyboru. Kwestionariusz opracowano w oparciu o międzynarodowy standardowy kwestionariusz z badań nad zachowaniami zdrowotnymi młodzieży szkolnej HBSC (Heath Behaviour in School-Aged Children: A WHO Collaborative cross-national study) [7], skalę D. Goldberga GHQ-12 (General Heath Questionnaire) [8], skalę E.S. Huebnera (Student's Life Satisfaction Scale, 1991) [9].

Ponieważ wszystkie pytania w części ankiety dotyczącej modelu odżywiania studentów skonstruowane były w taki sposób, że respondenci wskazać mogli jedynie zaproponowane warianty odpowiedzi, wyniki przedstawiono w tabelach wielodzielczych. Istotności różnic w częstościach występowania poszczególnych wariantów odpowiedzi w każdej z grup płci oceniono, stosując test $\chi^{2}$ Pearsona, który jest najbardziej rozpowszechnionym testem istotności dla zmiennych jakościowych. W przypadkach gdy test wykazywał istotność różnic w częstościach, analizowano także nadwyżki pomiędzy liczebnościami obserwowanymi i oczekiwanymi w poszczególnych polach tabeli. W sytuacjach, gdy liczebności w polach tabeli były zbyt małe, zastosowano poprawkę Yatesa.

Wartości wskaźnika masy ciała (body mass index - BMI) przedstawiono w postaci statystyk podstawowych osobno dla każdej z płci. Istotności różnic w średnich wartościach BMI analizowanych grup oceniono, stosując test t-Studenta dla zmiennych niezależnych, sprawdzając uprzednio równość wariancji w próbach testem F Fishera. Skategoryzowane wartości BMI przedstawiono w postaci tabeli wielodzielczej. Za poziom istotności przyjęto $\mathrm{p}<0,05$.

\section{WYNIKI}

Analiza wartości wskaźnika BMI badanych grup wykazała, że większość ze studentów prezentuje odpowiednie wartości wskaźnika w granicach 18,5-24,99\%, czyli odpowiednie proporcje masy ciała do wzrostu. W grupie mężczyzn istotnie częściej zaobserwowano występowanie nadwagi $(\mathrm{p}<0,05)$, w grupie kobiet niedowagi $(\mathrm{p}<0,05)$. W obu grupach nie obserwowano występowania problemu otyłości (ryc. 1).

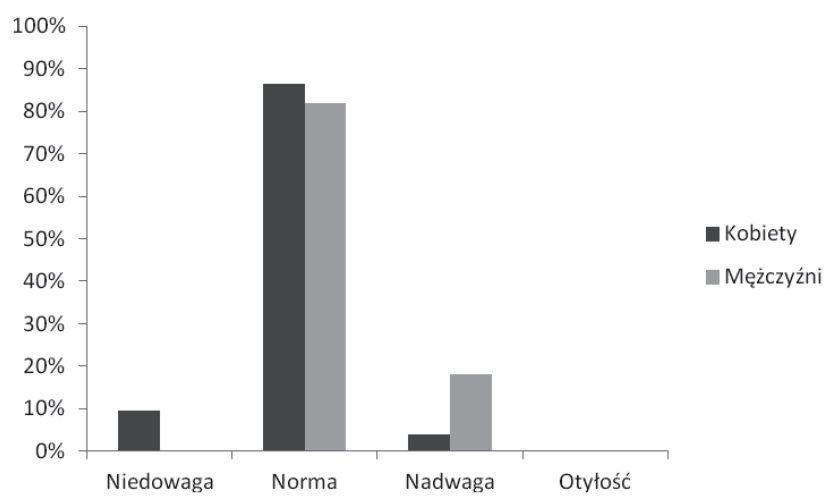

RYCINA 1. Wskaźnik masy ciała badanych grup studentów

W ankiecie oceniano regularność spożywanych posiłków. Nie stwierdzono istotnych różnic pomiędzy grupami mężczyzn i kobiet w częstości regularnego spożywania posiłków w ciągu tygodnia, poza częstszym spożywaniem podwieczorków przez mężczyzn. Tylko ok. 50\% badanej populacji deklaruje regularne spożywanie 3 podstawowych posiłków: śniadania, obiadu i kolacji (ryc. 2). W czasie weekendu studenci obojga płci istotnie częściej zjadają śniadania $-\chi^{2}$ Pearsona: 11,5076, df = 1 , $\mathrm{p}=, 000693$. Nie zaobserwowano istotnych różnic w spożywaniu pozostałych posiłków między studentami obojga płci.

Studenci zapytani zostali o stosowanie specyficznych diet oraz o określenie ich rodzaju. Wymieniono stosowanie diet: odchudzających, wegetariańskiej, wysokobiałkowej, niskowęglowodanowej i niskokalorycznej. Kobiety znacząco częściej od mężczyzn stosują dietę odchudzającą: $\chi^{2}$ Pearsona: 8,75032, $\mathrm{df}=1, \mathrm{p}=, 003096$. 


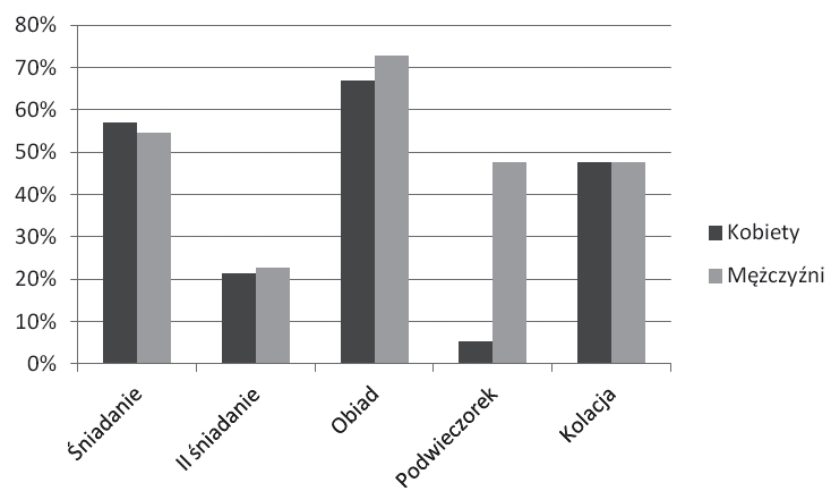

RYCINA 2. Rodzaj spożywanego posiłku w ciągu tygodnia

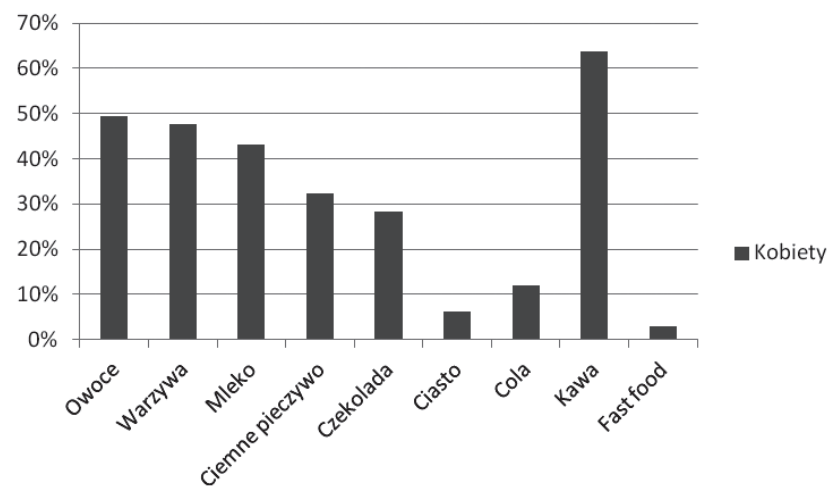

RYCINA 3. Struktura spożywanych pokarmów przez kobiety

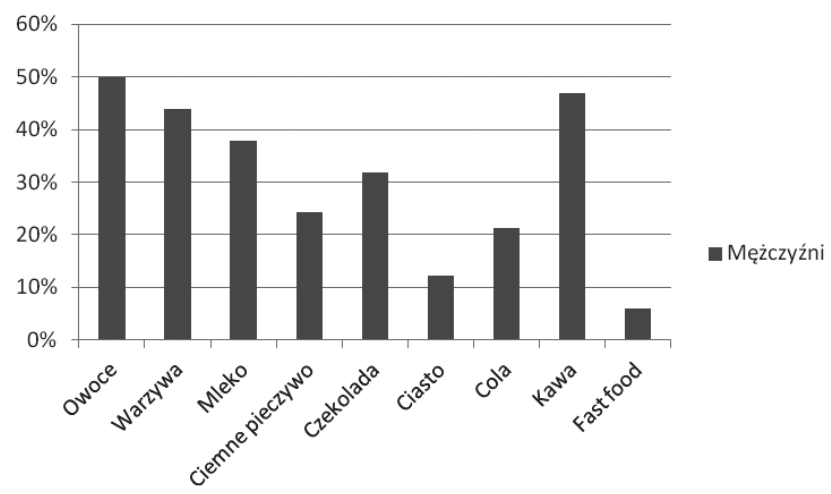

RYCINA 4. Struktura spożywanych pokarmów przez mężczyzn

Studenci znacząco częściej natomiast podejmowali działania mające na celu kontrolę masy ciała $-\chi^{2}$ Pearsona: $14,0301, \mathrm{df}=1$, $\mathrm{p}=, 000180$, a wyrażające się przede wszystkim podejmowaniem celowej aktywności fizycznej. Analiza rodzaju spożywanej żywności nie wykazała istotnych różnic w dziennej konsumpcji owoców i warzyw, mleka ani ciemnego pieczywa pomiędzy grupami kobiet i mężczyzn (ryc. 3, 4). Tylko 50\% młodzieży codziennie spożywa owoce i warzywa. Studentki znacząco częściej od mężczyzn piją codziennie kawę $-\chi^{2}$ Pearsona: 8,92867, $\mathrm{df}=1, \mathrm{p}=, 002808$, a studenci częściej spoży wają produkty typu fast food, jednak różnice nie są istotne statystycznie. Poziom spożywania codziennie produktów typu fast food odnotowano na dość niskim poziomie, zaledwie kilku procent.
Do jednych z najważniejszych zachowań prozdrowotnych należy przestrzeganie zasad zdrowego odżywiania oraz podejmowanie aktywności ruchowej. Dzięki propagowanej w środkach masowego przekazu wiedzy na temat wpływu aktywności fizycznej na zdrowie oraz promowaniu zdrowego odżywiania wzrasta powszechna świadomość społeczeństwa w tym zakresie. Dodatkowo młodzież rozpoczynająca studia medyczne ma dość obszerną wiedzę zdobytą w ramach rozszerzonego kursu biologii [10]. Pomimo to powszechnie obserwowane jest w badaniach prowadzonych wśród studentów uczelni wyższych zarówno w Polsce, jak i na świece narastanie zjawisk negatywnych, takich jak ograniczenie aktywności fizycznej, stosowanie używek i nieprzestrzeganie zasad zdrowego odżywiania się $[11,12,13,14,15]$. W przeprowadzonym badaniu stwierdzono, że tylko 50\% studentów regularnie spożywa w tygodniu i w weekendy podstawowe posiłki - śniadanie, obiad i kolację. Podobne obserwacje poczyniono, badając studentów Uniwersytetu Medycznego w Łodzi. Średnio tylko 37\% studentów spożywało 3 posiłki dziennie, a co 5. kobieta i co 6. mężczyzna spożywali posiłki w sposób nieregularny [10]. Badania przeprowadzone wśród młodzieży Akademii Medycznej w Białymstoku również wykazały nieregularność spożywania posiłków, częste pomijanie śniadań w codziennej diecie oraz niskie spożycie warzyw i owoców [16]. Dodatkowo, badania w Białymstoku wykazały przewagę modelu 4-posiłkowego w jadłospisie kobiet, a 3-posiłkowego u mężczyzn [6]. W badaniach własnych model 4-posiłkowy częściej występował u mężczyzn niż u kobiet (ryc. 2). Większą regularność zanotowano wśród studentów białostockich zamieszkujących dom rodzinny versus studentów akademików [6]. W badaniu własnym nie analizowano tego czynnika. Obserwowane zjawisko nieregularności posiłków jest bardzo niekorzystne. Regularne przyjmowanie posiłku zapobiega powstawaniu otyłości i pozwala na pełniejsze wykorzystanie składników odżywczych [6]. Tak jak w innych ośrodkach studenckich, zaobserwowano niepokojąco niskie spożycie warzyw i owoców, cennego źródła błonnika (ryc. 3, 4). Mniej niż połowa studentów codziennie spożywa te ważne produkty w diecie. Pozytywne zjawisko stanowi fakt, że towarzyszy temu dość rzadkie spożywanie produktów typu fast food i słodyczy. Spożycie napojów gazowanych jest wyższe - ok. 10\% kobiet i ok. 20\% mężczyzn spożywa je codziennie. W grupie kobiet występuje też wysokie spożycie kawy. Na pytania o stosowane diety ankietowani studenci podobnie do kolegów z uczelni medycznych w Łodzi [10] czy w Białymstoku [16] wskazywali diety niskokaloryczne lub wegetariańską. Większość badanych osób nie stosowała żadnych specjalnych diet; $4 \%$ kobiet stosuje dietę wegetariańską. Istotnie częściej kobiety stosują diety odchudzające. Według wyników badań prowadzonych wśród studentów w Łodzi [10] odnotowano najczęstsze stosowanie diet niskokalorycznych, których celem była redukcja masy ciała

Okres studiów to czas zmian w nawykach żywieniowych wynikających ze zmiany miejsca zamieszkania. Często oznacza 
to pierwsze samodzielne mieszkanie i konieczność przyrządzania sobie posiłków. Brak umiejętności w tym zakresie, duża ilość zajęć oraz czynniki ekonomiczne wpływają na utrwalanie negatywnych wzorców - nieregularności spożywania posiłków, ograniczenia ich liczby i pogorszenia jakości spożywanych produktów [6]. Często towarzyszy temu ograniczenie aktywności fizycznej oraz stosowanie używek [10,14, 15, 17, 18, 19]. W badanej grupie studentów we wcześniejszym opracowaniu również obserwowano te niepokojące zjawiska. Odsetek palaczy jest dość wysoki - ok. 30 u kobiet i 40 u mężczyzn, a ich aktywność fizyczna niedostateczna [14, 15]. Podobne odsetki osób palących obserwowano na Uniwersytecie Medycznym w Łodzi [17] i w Lublinie [18] oraz we Wrocławiu [5]. Aktywność fizyczna u studentów Uniwersytetu Medycznego w Łodzi [10], we Wrocławiu [5] była również na niskim poziomie. Pomimo niekorzystnych zjawisk dotyczących zarówno nieprawidłowego odżywiania, jak i niskiej aktywności fizycznej nie zauważono istotnych odchyleń w parametrach BMI badanych studentów. Większość z nich znajdowała się w przedziałach normy. Nadwaga obserwowana była u ok. 15\% studentów i 5\% studentek. Procent otyłych studentów jest zatem wyższy niż w grupie studentów uczelni Wrocławia, gdzie wahał się w granicach 7,7\% [5], natomiast zdecydowanie niższy w porównaniu z populacją studentów japońskich, gdzie problem otyłości obserwowano u ok. 30\% [4]. Ten wysoki stopień otyłości w populacji młodych ludzi wiązany jest z popularyzacją zachodniego stylu życia i diety bogatej w pokarmy typu fast food oraz słodkie gazowane napoje. Tendencja do spożywania tych pokarmów jest również niepokojąca w populacjach polskich. Badania ostatnich dekad pokazują w Polsce obniżenie spożycia produktów zbożowych i ziemniaków na rzecz wzrostu spożycia mięsa wieprzowego, tłuszczów zwierzęcych i roślinnych oraz cukru [4]. Nadal w Polsce obserwowane jest niskie spożycie ryb. Wynikać to może nie tylko ze względów ekonomicznych, gdyż stanowią dość drogi produkt spożywczy, ale przede wszystkich z braku tradycyjnych wzorców kulturowych [4].

W badaniach dotyczących modeli odżywiania zauważono wzrost spożycia kawy. W populacji polskiej jest jednak niższy niż w podobnych badaniach prowadzonych w Japonii [4]. Podobne zależności obserwowano w innych krajach. W badaniach przeprowadzonych w Grecji stwierdzono istotną zależność pomiędzy nieprawidłowym odżywianiem a paleniem tytoniu [20]. Podobne zjawiska obserwowano w Arabii Saudyjskiej, gdzie problem otyłości młodzieży zaczyna być wyzwaniem dla zdrowia publicznego [21], oraz wśród młodzieży pakistańskiej, u której obserwuje się wzrost częstości występowania cukrzycy typu 2 [22]. Niestety, badania prowadzone wśród polskiej młodzieży szkół wyższych również praktycznie wszędzie wykazują błędy dietetyczne oraz niski stopień aktywności fizycznej i wzrost stosowania używek $[4,5,10,14,15]$. Zjawiska te bardziej nasilone są na uczelniach o charakterze technicznym, wyższy stopień świadomości i przestrzegania zachowań prozdrowotnych obserwowany jest na uczelniach i kierunkach biologicznych $[14,23,24]$.
Problem występowania negatywnych zachowań zdrowotnych w grupie przyszłych lekarzy jest istotny nie tylko ze względu na wpływ na ich późniejsze zdrowie i życie, ale również na efekt oddziaływania na ich przyszłych pacjentów. Negatywne zachowania zdrowotne u przedstawicieli zawodów medycznych powinny być zdecydowanie minimalizowane $[17,19,25,26,27]$, a poszerzana wiedza na temat zdrowego trybu życia i umiejętności przekazywania tych zasad pacjentom. Kursy tego typu prowadzone dla studentów medycyny na Harvardzie pokazały nie tylko zmiany w ich zachowaniu, ale również większą troskę o tę sferę zachowań u pacjentów, z którymi mieli kontakt [28].

\section{WNIOSKI}

1. Studenci medycyny pomimo posiadanej wiedzy na temat zasad odżywiania, wynikającej z rozszerzonych programów biologii w szkole średniej, nie wdrażają jej w życie codzienne.

2. Grupa zawodowa przyszłych lekarzy powinna pełnić szczególna rolę w krzewieniu edukacji zdrowotnej i swoją postawą oraz zachowaniem być wzorem do naśladowania.

3. Niezwykle ważne jest kształtowanie wśród studentów medycyny prawidłowych wzorców prozdrowotnych, w tym prawidłowego odżywiania poprzez edukację żywieniową, która powinna mieć istotne miejsce w programie studiów.

\section{PIŚMIENNICTWO}

1. Chrzanowska M., Kozieł S., Ulijaszek S.J.: Changes In BMI and the prevalence of overweight and obesity in children and adolescents in Cracow, Poland, 1971-2000. Econ Hum Biol. 2007, 5 (3), 320-378.

2. Woynarowska B., Małkowska-Szkutnik A., Mazur J., Kowalewska A., Komosińska K.: School meals and policy on promoting healthy eating in schools in Poland. Med Wieku Rozwoj. 2011, 15 (3), 232-239.

3. Mazur J., Dzielska A., Małkowska-Szkutnik A.: Psychological determinants of selected eating behaviours in adolescents. Med Wieku Rozwoj. 2011, 15 (3), 240-249.

4. Morinaka T., Wozniewicz M., Jeszka J., Bajerska J., Nowaczyk P., Sone Y.: Westernization of dietary patterns among young Japanese and Polish females - a comparison study. Ann Agric Environ Med. 2013, 20 (1), 122-130.

5. Poręba R., Gać P., Zawadzki M., Poręba M., Derkacz A., Pawlas K. et al.: Styl życia i czynniki ryzyka chorób układu krążenia wśród studentów uczelni Wrocławia. Pol Arch Med Wew. 2008, 118, 1-9.

6. Stefańska E., Ostrowska L., Radziejewska I., Kardasz M.: Sposób żywienia studentów Uniwersytetu Medycznego w Białymstoku w zależności od miejsca zamieszkania w trakcie studiów. Probl Hig Epidemiol. 2010, 91, 585-590.

7. Currie C., Gabhainn N.C., Godeau E.: International HBSC Network Coordinating Committee. Health behaviour in school-aged children: WHO Collaborative Cross-National (HBSC) study: origins, concept, history and development 1982-2008. Int J Pub Health. 2009, 54, 131-139

8. Hubner E.S.: Initial development of the Student's Life Satisfaction Scale. Sch Psychol Int. 1991, 12, 231-240.

9. Goldberg D.: Kwestionariusz ogólnego stanu zdrowia GHQ-12 - załącznik 2. In: Ocena zdrowia psychicznego na podstawie badań kwestionariuszami Dawida Goldberga. Ed. B. Dudek. Insty tut Medycyny Pracy im. J. Nofera, Łódź, 2001.

10. Łaszek M., Nowacka E., Gawron-Skarbek A., Szatko F.: Negatywne wzorce zachowań zdrowotnych studentów. Część II. Aktywność ruchowa i nawyki żywieniowe. Probl Hig Epidemiol. 2011, 92, 461-465. 
11. Htay S.S., Oo M., Yoshida Y., Harun-Or-Rashid M., Sakamato J.: Risk behaviours and associated factors among medical students and community youths in Myanmar. Nagoya J Med Sci. 2010, 72 (1-2), 71-81.

12. Mazur J., Woynarowska B., Kołoło H.: Zdrowie subiektywne, styl życia i środowisko psychospołeczne młodzieży szkolnej w Polsce. Raport techniczny z badań HBSC 2006. Instytut Matki i Dziecka, Warszawa 2007.

13. Miller P.M., Heideman P.W., Ravenel M.C., Spangler J.G., Mauldin M.P., Hill E.G. et al.: Preliminary development and evaluation of online tobacco and alcohol modules for dental students. J Dent Educ. 2011, 75 (6), 791-796.

14. Gawlikowska-Sroka A., Dzięciołowska-Baran E., Szczurowski J., Teul I., Poziomkowska-Gęsicka I., Kamieńska E.: Cigarette smoking among students and the influence of legal regulations on passive smoking. Adv Exp Med Biol. 2013, 755, 189-194.

15. Gawlikowska-Sroka A., Dzięciołowska E., Szczurowski J., Kamieńska E. Czerwiński F.: Tobacco abuse and physical activity among medical students. Eur J Med Res. 2009, 14, 86-89.

16. Ostrowska L., Czapska D., Karczewski J.: Ocena nadwagi i otyłości oraz nawyków żywieniowych studentów Akademii Medycznej w Białymstoku. Brom Chem Toks. 2000, 33, (2), 125-131.

17. Łaszek M., Nowacka E., Szatko F.: Negatywne wzorce zachowań zdrowotnych studentów. Część I. Konsumpcja alkoholu i stosowanie substancji psychoaktywnych. Probl Hig Epidemiol. 2011, 92, 114-119.

18. Wójtowicz-Chomicz K., Kowal M., Wójtowicz M., Borzęcki A.: Próba oceny zachowań anty-zdrowotnych studentów Akademii Medycznej w Lublinie. Probl Hig Epidemiol. 2007, 88, 108-111.

19. Arnett M.R., Baba N.Z.: Improving tobacco dependence education among the Loma Linda University School of Dentistry faculty. J Dent Educ. 2011, 75 (6), 832-888.
20. Giannakopoulos G., Panagiotakos D., Mihas C., Tountas Y.: Adolescent smoking and health-related behaviours: interrelations in a Greek school-based sample. Child Care Health Dev. 2009, 35 (2), 164-170.

21. Al-Muammar M.N., El-Shafie M., Feroze S.: Association between dietary habits and body mass index of adolescent females in intermediate schools in Riyadh, Saudi Arabia. East Mediterr Health J. 2014, 20 (1), 39-45.

22. Nisar R., Qadri M.H., Fatima K., Perveen S.: Dietary habits and life style among students of private medical University Karachi. J Pak Med Assoc. 2008, 58 (12), 687-690.

23. Medrela-Kuder E.: Ocena stylu życia studentów fizjoterapii i edukacji techniczno-informatycznej na podstawie żywienia i aktywności fizycznej. Rocz Panstw Zakl Hig. 2011, 62, 315-318.

24. Likus W., Milka D., Bajor G., Jachacz-Łopata M., Dorzak B.: Dietary habits and physical activity in students from Medical University of Silesia in Poland. Rocz Panstw Zakl Hig. 2013, 64, 317-324.

25. Miller P.M., Heideman P.W., Ravenel M.C., Spangler J.G., Mauldin M.P., Hill E.G. et al.: Preliminary development and evaluation of online tobacco and alcohol modules for dental students. J Dent Educ. 2011, 75, 791-796.

26. Patelarou E., Vardavas C.I., Ntzilepi P., Warren C.W., Barbouni A., Kreemastinou J. et al.: Nursing education and beliefs towards tobacco cessation and control: a cross-sectional national survey (GHPSS) among nursing students in Greece. Tob Induc Dis. 2011, 9 (4).

27. Anis N.A., Lee R.E., Ellerbeck E.F., Nazir N., Greiner K.A., Ahluwalia J.S.: Direct observation of physician counseling on dietary habits and exercise: patients, physician, and office correlates. Prev Med. 2004, 38 (2), 198-202.

28. Conroy M.B., Delichatsios H.K., Hafler J.P., Rigotti N.A.: Impact of a preventive medicine and nutrition curriculum for medical students. Am J Prev Med. 2004, 27 (1), 77-80. 